\title{
Cell Migration Induced by Native Type IV Collagen Requires PI3K/Akt2 and EGFR Activity in MDA-MB-231 Breast Cancer Cells
}

\section{Emmanuel Reyes-Uribe, Octavio Galindo-Hernandez, Pedro Cortes-Reynosa, Eduardo Perez Salazar}

Departamento de Biologia Celular, Cinvestav-IPN. Mexico, Mexico

Email address:

jperez@cell.cinvestav.mx (E. P. Salazar)

\section{To cite this article:}

Emmanuel Reyes-Uribe, Octavio Galindo-Hernandez, Pedro Cortes-Reynosa, Eduardo Perez Salazar. Cell Migration Induced by Native Type IV Collagen Requires PI3K/Akt2 and EGFR Activity in MDA-MB-231 Breast Cancer Cells. Cancer Research Journal.

Vol. 3, No. 3, 2015, pp. 52-62. doi: 10.11648/j.crj.20150303.12

\begin{abstract}
Basement membrane (BM) is a specialized extracellular matrix (ECM) that separates epithelial cells from surrounding stroma and regulates various biological processes including morphology, growth, differentiation, adhesion and motility. Type IV collagen is the major component of BM, provides structural framework of all BMs and interacts with cell surface receptors including integrins and discoidin domain receptors (DDRs). The DDRs are receptor tyrosine kinases that get activated by collagens in their native triple-helical form and present sustained and slow activation kinetics. Particularly, DDR1 signaling mediates differentiation, immune response, migration and wound healing. However, the signal transduction pathways involved in cell migration induced by native IV collagen in breast cancer cells has been poorly studied. Here we demonstrate that native type IV collagen induces Akt2 and FAK activation through a DDR1, PI3K and epidermal growth factor receptor (EGFR)-dependent pathway in MDA-MB-231 breast cancer cells. In addition, cell migration induced by native type IV collagen requires PI3K, Akt2 and EGFR activity, whereas collagen IV also induces NFאB-DNA binding activity through a DDR1, PI3K, Akt2 and EGFR-dependent pathway. In summary, we demonstrate that migration induced by native type IV collagen requires PI3K/Akt2 and EGFR activity in MDA-MB-231 breast cancer cells.
\end{abstract}

Keywords: Collagen IV, DDR1, Akt2, PI3K, EGFR, Breast Cancer

\section{Introduction}

The extracellular matrix (ECM), including the basement membrane (BM), is a network of interacting molecules including collagens, fibronectin and laminin, which stabilizes the physical structures of tissues and regulates several cell processes [1]. Tumor invasion and metastasis require ECM degradation and tissue remodeling, whereas the ability to degrade and penetrate BM has been related with an increased potential for metastasis [2, 3]. BM is a continuous deposit that separates epithelial cells from the stroma, and it regulates cell morphology, growth, differentiation and promotes adhesion and motility of normal and transformed cells. The main component of BM is the type IV collagen, which provides structural framework of all BMs and interacts with cell surface molecules including integrins, proteoglycans and discoidin domain receptors (DDRs) [4-6].
DDR1 and DDR2 are receptor tyrosine kinases (RTKs) characterized for an extracellular domain of strong homology to the Dictyostelium discoideum protein discoidin that bind to and get activated by collagens in its native triple-helical form. In solid tissues, DDR1 expression is restricted to epithelial cells and is activated by collagens type I to VI and type VIII, whereas DDR2 is restricted to mesenchymal cells and is activated by collagens including type I, III and X [6, 7]. DDRs have a slow activation process compared to other RTKs, and they require hours to achieve maximal tyrosine phosphorylation and then their activation, which is sustained for several days. Particularly, DDR1 signaling mediates differentiation, immune response, migration, wound healing and cancer progression [6, 8-10].

The phosphatidyl inositol 3-kinase (PI3K)/Akt (protein 
kinase B) signaling pathway plays an essential role in several cell processes including proliferation, growth, survival, angiogenesis and cancer $[11,12]$. The PI3K family consists of three classes of lipid kinases composed of one catalytic and one regulatory subunit, which phosphorylates the 3'-hydroxyl group of phosphatidylinositols and generate molecules that act as second messengers in a number of intracellular signaling pathways, including the activation of PDK and Akt [13]. The class IA PI3Ks are the most widely implicated in cancer, with catalytic subunits that comprise $\mathrm{p} 110 \alpha, \mathrm{p} 110 \beta, \mathrm{p} 110 \gamma$ and $\mathrm{p} 110 \delta$, which have the capability of binding to their regulatory subunits $\mathrm{p} 85 \alpha, \mathrm{p} 85 \beta$ and $\mathrm{p} 55 \gamma[14,15]$. The Akt family of serine-threonine kinases is the primary downstream mediator of PI3K, and has three isoforms, namely Akt1, Akt2 and Akt3, which share a similar domain structure with an N-terminal pleckstrin homology $(\mathrm{PH})$ domain, a central kinase domain and one C-terminal domain that contains a hydrophobic domain (HD). Akt maximal activation requires the phosphorylation at two sites, one in the kinase domain (Thr-308, Thr-309, Thr-305 in Akt1, Akt2 and Akt3, respectively), and another in the C-terminal domain (Ser-473, Ser-474, Ser-472 in Akt1, Akt2 and Akt3, respectively) [11, $12,16]$.

In the present study we demonstrate, for the first time, that native type IV collagen induces Akt2 and FAK activation through a DDR1, PI3K and epidermal growth factor receptor (EGFR)-dependent pathway in MDA-MB-231 breast cancer cells. In addition, we demonstrate that cell migration induced by native type IV collagen requires PI3K, Akt2 and EGFR activity, whereas collagen IV also induces NFKB-DNA binding activity through a DDR1, PI3K, Akt2 and EGFR-dependent pathway.

\section{Materials and Methods}

\subsection{Materials}

Focal adhesion kinase (FAK) antibody (Ab) C-20, Akt2 Ab (F-7), Akt1 Ab (5C10), DDR1 Ab (H-126), phosphospecific $\mathrm{Ab}$ to tyrosine PY20 and imatinib mesylate were obtained from Santa Cruz Biotechnology, Inc (Santa Cruz, CA). Wortmannin and AG1478 were obtained from Calbiochem-Merck Millipore (Darmstadt, Germany). A6730 compound was obtained from Sigma-Aldrich Co. (St. Louis, MO). Phosphospecific Ab to Ser-473 of Akt (anti-p-Akt Ab) was obtained from Cell Signaling (Danvers, MA). Phosphospecific Ab to Tyr-397 of FAK (anti-p-FAK Ab) was obtained from Thermo Fisher Scientific Inc. (NYSE:TMO). Anti- $\alpha$-actin $A b$ was kindly provided by Dr. Manuel Hernandez (Cinvestav-IPN, Mexico). $\left[\gamma^{-32} \mathrm{P}\right]$ ATP was obtained from Perkin-Elmer (Boston, MA). Micro Bradford protein assay reagent was from Bio-Rad (Hercules, CA). All other reagents used were of the highest grade available.

\subsection{Extraction and Purification of Type IV Collagen}

Type IV collagen was extracted and purified from human placenta as described previously $[17,18]$. Purity of type IV collagen was verified by SDS-PAGE and Coomasie stain. Our preparation showed a typical pattern of type IV collagen without any contaminants bands.

\subsection{Cell Culture}

MDA-MB-231 breast cancer cells were cultured in Dulbecco's modified Eagle's medium (DMEM) supplemented with $3.7 \mathrm{~g} / 1$ sodium bicarbonate, $5 \%$ fetal bovine serum (FBS) and antibiotics, in a humidified atmosphere containing $5 \% \mathrm{CO}_{2}$ and $95 \%$ air at $37{ }^{\circ} \mathrm{C}$. For experimental purposes, cells were starved in DMEM without FBS for $24 \mathrm{~h}$, before treatment with inhibitors and/or native type IV collagen.

\subsection{Cell Stimulation}

Cell stimulation was performed as described previously [19]. Briefly, confluent cultures were washed with phosphate buffered saline (PBS) and treated with inhibitors and/or with a solution of type IV collagen in DMEM (native type IV collagen) without FBS for the times indicated. Stimulation was terminated by aspirating the medium (conditioned medium), and cells were solubilized in $0.25 \mathrm{ml}$ of ice-cold RIPA buffer (50 mM HEPES pH 7.4, $150 \mathrm{mM} \mathrm{NaCl}, 1 \mathrm{mM}$ EGTA, $1 \mathrm{mM}$ sodium orthovanadate, $100 \mathrm{mM} \mathrm{NaF}, 10 \mathrm{mM}$ sodium pyrophosphate, $10 \%$ glycerol, $1 \%$ Triton $\mathrm{X}-100,1 \%$ sodium deoxycholate, $1.5 \mathrm{mM} \mathrm{MgCl}, 0.1 \%$ SDS and $1 \mathrm{mM}$ phenylmethylsulfonyl fluoride).

\subsection{Immunoprecipitation}

Equal amounts of protein $(700 \mu \mathrm{g})$ were immunoprecipitated overnight at $4{ }^{\circ} \mathrm{C}$ with protein A-agarose linked to anti-FAK $\mathrm{Ab}(1 \mu \mathrm{g})$ or anti-Akt2 $\mathrm{Ab}(1 \mu \mathrm{g})$. Immunoprecipitates were washed three times with RIPA buffer and extracted in $2 \times$ SDS-PAGE sample buffer $(200$ $\mathrm{mM}$ Tris- $\mathrm{HCl} \mathrm{pH}$ 6.8, $1 \mathrm{mM}$ EDTA, 6\% $\mathrm{SDS}, 4 \%$ 2-mercaptoethanol, $10 \%$ glycerol) by boiling $5 \mathrm{~min}$ and resolved by SDS-PAGE.

\subsection{Western Blotting}

Proteins were separated by SDS-PAGE using 10\% separating gels followed by transfer to nitrocellulose membranes. After transfer, membranes were blocked using 5\% non-fat dried milk in phosphate buffered saline (PBS) pH 7.2 / $0.1 \%$ Tween 20 (wash buffer), and incubated overnight at $4{ }^{\circ} \mathrm{C}$ with primary $\mathrm{Ab}$. The membranes were washed three times with wash buffer and incubated with secondary $\mathrm{Ab}$ (horseradish peroxidase-conjugated) $(1: 5000)$ for $2 \mathrm{~h}$ at $25^{\circ} \mathrm{C}$. After washing three times with wash buffer, the immunoreactive bands were visualized using ECL detection reagent. Autoradiographs were scanned and the labeled bands were quantified using the Image $\mathrm{J}$ software (NIH, USA).

\subsection{Interference $\mathrm{RNA}$}

DDR1 and Akt2 expressions were silenced in MDA-MB-231 cells by using the silencer siRNAs kit from 
Santa Cruz Biotechnology, according to the manufacture's guidelines and $0.3 \mu \mathrm{M}$ DDR 1 and $0.3 \mu \mathrm{M}$ Akt2 siRNAs. One control of scramble siRNAs $(0.3 \mu \mathrm{M})$ was included according to the manufacture's guidelines.

\subsection{Scratch-Wound Assay}

MDA-MB-231 cells were grown to confluence on 35-mm culture dishes, starved for $24 \mathrm{~h}$ in DMEM, and treated for $2 \mathrm{~h}$ with $12 \mu \mathrm{M}$ mitomycin $\mathrm{C}$ to inhibit proliferation during the experiment. Cultures were scratch-wounded using a sterile 200- $\mu$ l pipette tip, washed twice with PBS and re-fed with DMEM without or with inhibitors and native type IV collagen for the times and concentrations indicated. The progress of cell migration into the wound was photographed at $48 \mathrm{~h}$ using an inverted microscope coupled to a camera. Each experimental condition was repeated three times. Cell migration was evaluated by quantification of open wound area using the T-scratch image analysis software.

\subsection{Preparation of Nuclear Extracts}

Nuclear extracts were prepared as described previously [17] Briefly, confluent cultures of MDA-MB-231 cells were stimulated without or with $7 \mu \mathrm{g} / \mathrm{ml}$ native type IV collagen for various times. Cells were lysed with $0.1 \%$ nonionic detergent Nonidet P40 in Buffer A (10 mM Tris- HCl, pH 7.4, $10 \mathrm{mM}$ $\mathrm{NaCl}, 6 \mathrm{mM} \mathrm{MgCl} 2,10 \mathrm{mM} \mathrm{NaF}, 1 \mathrm{mM} \mathrm{Na} \mathrm{VO}_{4}, 1 \mathrm{mM}$ DTT, $1 \mathrm{mM}$ PMSF), lysates were pelleted at 2,600 rpm for $5 \mathrm{~min}$ and resuspended in Buffer $\mathrm{B}$ (20 mM HEPES, pH 7.9, 420 $\mathrm{mM} \mathrm{NaCl}, 20 \%$ glycerol $1.5 \mathrm{mM} \mathrm{MgCl}_{2}, 0.2 \mathrm{mM}$ EDTA, 1 $\mathrm{mM} \mathrm{Na} \mathrm{VO}_{4}, 10 \mathrm{mM} \mathrm{NaF}, 1 \mathrm{mM}$ DTT, $0.2 \mathrm{mM}$ PMSF). Nuclear extracts were recovered by centrifugation at 12,000 rpm for $15 \mathrm{~min}$ at $4{ }^{\circ} \mathrm{C}$ and the protein level of each sample was determined by the micro Bradford protein assay.

\subsection{Electrophoretic Mobility Shift Assay (EMSA)}

Nuclear extracts were prepared as described above. Double-strand oligonucleotide containing specific binding sites for NFkB, 5'-AGCTAAGGGACTTTCCGCTGGGGACTTTCCAGG-3', was used as probe [20]. An amount of $20 \mathrm{pmol}$ of annealed oligonucleotide was labeled with $\left[\gamma_{-}{ }^{32} \mathrm{P}\right]$ ATP using T4 polynucleotide kinase. The ${ }^{32} \mathrm{P}$-labeled oligonucleotide probe $(\sim 1 \mathrm{ng})$ was incubated with $7 \mu \mathrm{g}$ of nuclear extract in a reaction mixture containing $3 \mu \mathrm{g}$ poly (dI-dC), 0.25 M HEPES pH 7.5, 0.6 M KCl, $50 \mathrm{mM}$ $\mathrm{MgCl}_{2}, 1 \mathrm{mM}$ EDTA, $7.5 \mathrm{mM}$ DTT, and 9\% glycerol for 20 min at $4{ }^{\circ} \mathrm{C}$. One hundred-fold excess of unlabeled specific was used as specific competitor. The samples were fractionated on a $6 \%$ polyacrylamide gel in $0.5 \mathrm{x}$ Tris borate-EDTA buffer. Gels were dried and analyzed by autoradiography.

\subsection{Statistical Analysis}

Results are expressed as mean \pm S.D. Data were statistically analyzed using t-student unpaired test, one-way ANOVA and Tukey or Newman-Keuls multiple comparison tests. Statistical probability of $\mathrm{P}<0.05$ was considered significant.

\section{Results}

\subsection{Native Type IV Collagen Induces Akt2 Activation in MDA-MB-231 Cells}

DDRs are activated only when collagen is in its native triple helical form. We previously demonstrated that stimulation of MDA-MB-231 cells with $7 \mu \mathrm{g} / \mathrm{ml}$ type IV collagen in solution (native type IV collagen) induced DDR1 tyrosine phosphorylation (activation) in a time-dependent manner, reaching two peaks of maximum tyrosine phosphorylation at 10 and $25 \mathrm{~h}$ of treatment [19]. Therefore, we performed the following experiments by stimulation of MDA-MB-231 cells with $7 \mu \mathrm{g} / \mathrm{ml}$ type IV collagen in solution (native type IV collagen). First, we further substantiate our previous findings that native type IV collagen induces DDR1 activation, we stimulated MDA-MB-231 cells for 10 and $25 \mathrm{~h}$ with $7 \mu \mathrm{g} / \mathrm{ml}$ type IV collagen in solution and with denatured type IV collagen, which was prepared by healing the native type IV collagen solution at $90^{\circ} \mathrm{C}$ for $50 \mathrm{~min}$. Cells were lysed and immunoprecipitated (IP) with anti-DDR $1 \mathrm{Ab}$ and the immune complexes were analyzed by Western blotting with phosphospecific Ab to tyrosine PY20. Our results showed that native IV collagen induced DDR1 tyrosine phosphorylation, whereas denatured collagen did not induce DDR1 phosphorylation (Fig. 1A).

We examined whether native type IV collagen induces Akt2 activation. Cultures of MDA-MB-231 cells were stimulated with $7 \mu \mathrm{g} / \mathrm{ml}$ native type IV collagen for various times and lysed. Cell lysates were IP with anti-Akt $2 \mathrm{Ab}$ and analyzed by SDS-PAGE followed by Western blotting with anti-p-Akt Ab, which recognizes the phosphorylation on Ser-473 and Ser-474 of Akt1 and Akt2 respectively. As illustrated in Fig. 1B (upper panel), treatment of MDA-MB-231 cells with native type IV collagen induced an increase on Akt 2 phosphorylation at Ser-474 (p-Akt2) that reached at maximum between 3 and $6 \mathrm{~h}$ of treatment. Western blotting with anti-Akt2 Ab of the same membranes was used as loading control (Fig. 1B, lower panel).

Since, we demonstrated that native type IV collagen induces DDR1 activation [19], and that native type IV collagen induces Akt2 activation in MDA-MB-231 cells. We determined the role of DDR1 on Akt2 activation. The imatinib compound was used to study the role of DDR1 on Akt2 activation. Imatinib mesylate is an inhibitor of c-Abl tyrosine kinase, PDGFR and tyrosine kinases associated with c-kit [21]. However, it has been recently reported that imatinib mesylate used in the range of $30-100 \mathrm{nM}$ concentration is a selective inhibitor of DDR1 kinase activity [22, 23]. MDA-MB-231 cells were treated for $2 \mathrm{~h}$ with $100 \mathrm{nM}$ imatinib and stimulated with $7 \mu \mathrm{g} / \mathrm{ml}$ native type IV collagen for another $24 \mathrm{~h}$, and cells were lysed. Lysates were IP with anti-Akt2 Ab, followed by Western blotting with anti-p-Akt Ab. Our results showed that treatment with imatinib completely inhibit p-Akt2 induced by native type IV collagen (Fig. 1C).

Akt is the primary downstream mediator of PI3K signaling. We determined whether Akt2 activation, given by its phosphorylation at Ser-474, requires PI3K activity. 
MDA-MB-231 cells were treated for $2 \mathrm{~h}$ with $100 \mathrm{nM}$ wortmannin, an inhibitor used to inhibit PI3K activity in MDA-MB-231 cells [24], and then stimulated with $7 \mu \mathrm{g} / \mathrm{ml}$ native type IV collagen for $24 \mathrm{~h}$. Cells were lysed and lysates were IP with anti-Akt2 Ab, followed by Western blotting with anti-p-Akt Ab. As illustrated in Fig. 1C, p-Akt2 induced by native type IV collagen required $\mathrm{PI} 3 \mathrm{~K}$ activity.

\subsection{Native Type IV Collagen Induces FAK Activation Through a DDR1/PI3K-Dependent Pathway}

Since, we demonstrated that native type IV collagen induces migration through a DDR1-dependent pathway in MDA-MB-231 cells [25]. We determined whether native type IV collagen induces FAK activation, because it is implicated in the migration process. MDA-MB-231 cells were treated with $7 \mu \mathrm{g} / \mathrm{ml}$ native type IV collagen for various times and lysed. FAK activation, given by its phosphorylation at Tyr-397 (p-FAK), was analyzed by immunoprecipitation with anti-FAK $\mathrm{Ab}$ and Western blotting with anti-p-FAK Ab. As shown in Fig. 2A, treatment of cells with native type IV collagen resulted in a biphasic p-FAK response, with two peaks of phosphorylation at 3 and $12 \mathrm{~h}$ of treatment.

Next, we determined whether FAK activation induced by native type IV collagen required DDR 1 and PI3K activity. MDA-MB-231 cells were treated for $2 \mathrm{~h}$ with $100 \mathrm{nM}$ imatinib or $100 \mathrm{nM}$ wortmannin, stimulated with $7 \mu \mathrm{g} / \mathrm{ml}$ native type IV collagen for $24 \mathrm{~h}$ and lysed. FAK activation was analyzed by immunoprecipitation with anti-FAK $\mathrm{Ab}$ and Western blotting with anti-p-FAK Ab. As shown in Fig. 2B, FAK activation induced by native type IV collagen required DDR1 and PI3K activity.

\subsection{Native Type IV Collagen Mediates Cell Migration Through a PI3K/Akt2-Dependent Pathway}

Native type IV collagen induces migration of MDA-MB-231 cells [25]. We determined the role of PI3K and Akt activity on cell migration. Cultures of MDA-MB-231 cells were treated for $2 \mathrm{~h}$ with $100 \mathrm{nM}$ wortmannin or $2 \mu \mathrm{M}$ A6730, which is a selective inhibitor of Akt1/2 activity [26]. Cell cultures were scratch-wounded and treated with $7 \mu \mathrm{g} / \mathrm{ml}$ native type IV collagen for $48 \mathrm{~h}$. Our results showed that native type IV collagen induced migration and that it is dependent on PI3K and Akt1/2 activity in MDA-MB-231 cells (Fig. 3A and B).

Next, we studied the role of Akt 2 on cell migration induced by native type IV collagen. Cell migration assays were performed by using scratch wound assays and MDA-MB-231 cells, in which Akt 2 expression was knocked down by using siRNA against Akt2 (Fig. 3C), and treated with $7 \mu \mathrm{g} / \mathrm{ml}$ native type IV collagen for $48 \mathrm{~h}$. As shown in Fig. 3D and E, inhibition of Akt2 expression prevented migration induced by native type IV collagen in MDA-MB-231 cells.

\subsection{DDR1 Mediates the Increase of NF KB-DNA Binding Activity Induced by Native Type IV Collagen}

Since, NFkB is able to be activated by Akt [27]. We determined whether native type IV collagen induces NFkB-DNA binding activity. Cultures of MDA-MB-231 cells were stimulated for various times with $7 \mu \mathrm{g} / \mathrm{ml}$ native type IV collagen and nuclear extracts were obtained. NFKB-DNA binding activity was analyzed by EMSA using nuclear extracts and a radiolabeled oligonucleotide probe representing a canonical NFKB binding site. As shown in Fig. 4A, treatment of cells with native type IV collagen induced an increase of NFKB-DNA complex formation in a time-dependent manner, with a maximum of binding at $24 \mathrm{~h}$ of treatment. The specificity of these complexes was demonstrated by inhibition of binding in the presence of a cold competitor.

Next, we determined whether DDR1 mediates NFKB-DNA binding activity. MDA-MB-231 cells were treated for $2 \mathrm{~h}$ with different concentrations of imatinib $(22,33,60 \mathrm{nM})$, stimulated with $7 \mu \mathrm{g} / \mathrm{ml}$ native type IV collagen for $24 \mathrm{~h}$, nuclear extracts were obtained and analyzed by EMSA. As illustrated in Fig. 4B, treatment with different concentrations of imatibib inhibited the increase of NFKB-DNA binding activity induced by native type IV collagen. To further substantiate our findings, EMSAs were performed by using nuclear extracts from MDA-MB-231 cells treated with 7 $\mu \mathrm{g} / \mathrm{ml}$ native type IV collagen for $24 \mathrm{~h}$, in which DDR 1 expression was knocked down by using siRNA DDR1 (Fig. 4C). Our findings showed that inhibition of DDR1 expression inhibited the increase of NFKB-DNA binding activity induced by native type IV collagen (Fig. 4D).

\subsection{Role of DDR1 and PI3K/Akt2 on the Increase of NF KB-DNA Binding Activity Induced by Native Type IV Collagen}

We studied the role of PI3K/Akt on the increase of NFKB-DNA binding activity induced by native IV collagen. MDA-MB-231 cells were treated for $2 \mathrm{~h}$ with $100 \mathrm{nM}$ wortmannin and $2 \mu \mathrm{M}$ A6730, treated for $24 \mathrm{~h}$ with $7 \mu \mathrm{g} / \mathrm{ml}$ native type IV collagen. Nuclear extracts were obtained and EMSAs were performed. As shown in Fig. 4B and D, inhibition of PI3K and Akt1/2 activity inhibited the increase of NFKB-DNA binding activity induced by native type IV collagen.

In order to determine the participation of Akt2, EMSAs were performed by using nuclear extracts from MDA-MB-231 cells treated for $24 \mathrm{~h}$ with $7 \mu \mathrm{g} / \mathrm{ml}$ native type IV collagen, in which Akt2 expression was knocked down by using siRNA Akt2 (Fig. 4A). Our findings showed that inhibition of Akt2 expression prevented the increase of NFkB-DNA binding activity induced by native type IV collagen (Fig. 4D).

\subsection{Role of EGFR on Cell Migration and NFKB-DNA Binding Activity Induced by Native Type IV Collagen}

Since, we previously demonstrated that native type IV collagen induces secretion of gelatinases through an EGFR-dependent pathway in breast cancer cells [19]. We studied the role of EGFR on Akt2 and FAK activation, migration and NFKB-DNA binding activity induced by native 
type IV collagen.

In order to determine the role of EGFR on Akt 2 and FAK activation induced by native type IV collagen, MDA-MB-231 cells were treated for $2 \mathrm{~h}$ with $500 \mathrm{nM}$ AG1478, which is a selective inhibitor of EGFR activity [28], treated with $7 \mu \mathrm{g} / \mathrm{ml}$ native type IV collagen for $24 \mathrm{~h}$ and lysed. Activation was analyzed by Western blot using anti-p-Akt2 $\mathrm{Ab}$ and anti-p-FAK $\mathrm{Ab}$. Our findings showed that treatment with EGFR inhibitor completely blocked the activation of FAK and Akt2 (p-FAK and p-Akt2) induced by native type IV collagen (Fig. 5A and B).

A

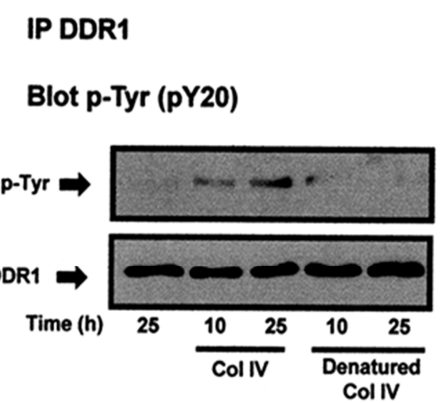

B

IP: Akt2

Blot p-Akt2

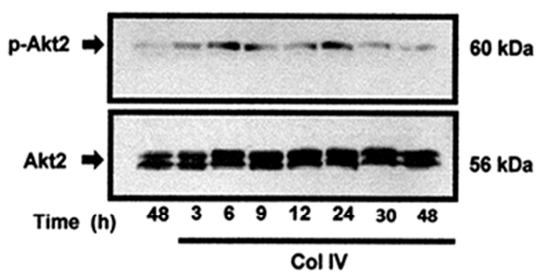

C

IP: Akt2

Blot p-Akt2

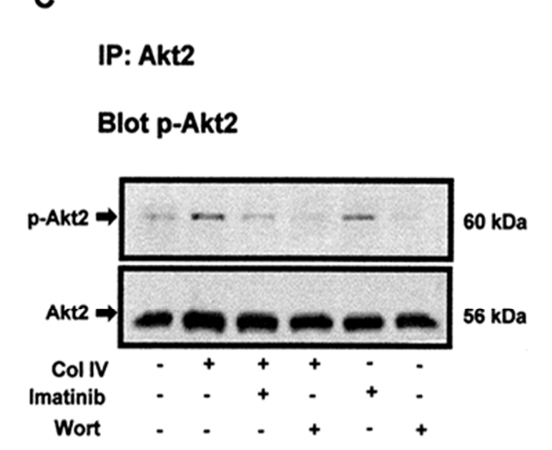

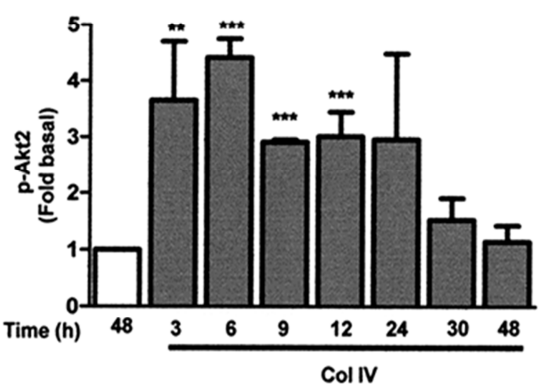

Col IV

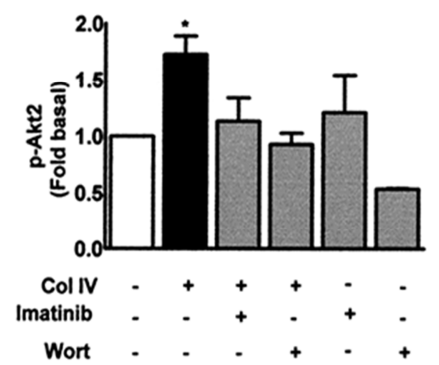

Figure 1. Native type IV collagen induces Akt2 activation through a DDR1 and PI3K-dependent pathway in MDA-MB-231 breast cancer cells. Panel A. $M D A-M B-231$ cells were treated for 10 and $25 \mathrm{~h}$ with $7 \mu \mathrm{g} / \mathrm{ml}$ type IV collagen in solution and with denatured type IV collagen, which was prepared by healing the native type IV collagen solution at $90{ }^{\circ} \mathrm{C}$ for $50 \mathrm{~min}$. Cells were lysed and immunoprecipitated (IP) with anti-DDRI Ab and the immune complexes were analyzed by Western blotting with phosphospecific Ab to tyrosine PY20. The membranes were analyzed further by Western blotting with anti-DDR1 Ab. Panel B. MDA-MB-231 cells were treated without or with $7 \mu \mathrm{g} / \mathrm{ml}$ type IV collagen in solution (Col IV) for the indicated times and lysed. Panel C. MDA-MB-231 cells were treated without (-) or with (+) $100 \mathrm{nM}$ imatinib or $100 \mathrm{nM}$ wortmannin (Wort), stimulated with $7 \mu \mathrm{g} / \mathrm{ml} \mathrm{Col} \mathrm{IV} \mathrm{for} 24 \mathrm{~h}$ and lysed. Lysates were analyzed by immunoprecipitation (IP) with anti-Akt2 Ab followed by Western blotting with anti-p-Akt Ab. The membranes were analyzed further by Western blotting with anti-Akt2 Ab. The graphs represent the mean $\pm S$ S.D. of at least three independent experiments and are expressed as fold of p-Akt2 above untreated cells (Control). Asterisks denote comparisons made to untreated cells. $* P<0.05, * * P<0.01$, ***P<0.001.

To determine the role of EGFR on cell migration, cultures of MDA-MB-231 cells were treated for $2 \mathrm{~h}$ with $500 \mathrm{nM}$ AG1478. Cell cultures were scratch-wounded and treated with $7 \mu \mathrm{g} / \mathrm{ml}$ native type IV collagen for $48 \mathrm{~h}$. Our results showed that inhibition of EGFR activity inhibited the migration induced by native type IV collagen (Fig 5C and D). To study the role of EGFR on the increase of NFKB-DNA binding activity induced by native type IV collagen. MDA-MB-231 cells were treated for $2 \mathrm{~h}$ with $500 \mathrm{nM}$ AG1478, treated for 24 $\mathrm{h}$ with $7 \mu \mathrm{g} / \mathrm{ml}$ native type IV collagen, nuclear extracts were obtained and EMSAs were performed. Our findings showed that inhibition of EGFR activity prevented the increase of NFkB-DNA binding activity induced by native type IV collagen (Fig. 5E). 


\section{Discussion}

In normal conditions, ECM mediates several cell functions including differentiation, polarity and survival. However, during the metastasis process, there is a disruption of physiological interactions of tumor cells with the surrounding ECM, which contributes to migratory and invasive programs [29].

In the normal mammary gland, $\mathrm{BM}$ is a continuous deposit that separates epithelial cells from surrounding stroma, and is the first barrier that cancer cells must traverse to produce metastasis. The integrins and DDRs are the most widely expressed collagen receptors in cells, which activate specific signaling pathways and responses. Particularly, DDR1 is activated by native type IV collagen and does not require the activity of collagen-binding integrins [30]. However the signal transduction pathways induced by activation of DDR1 with type IV collagen has been poorly described.

\section{A}
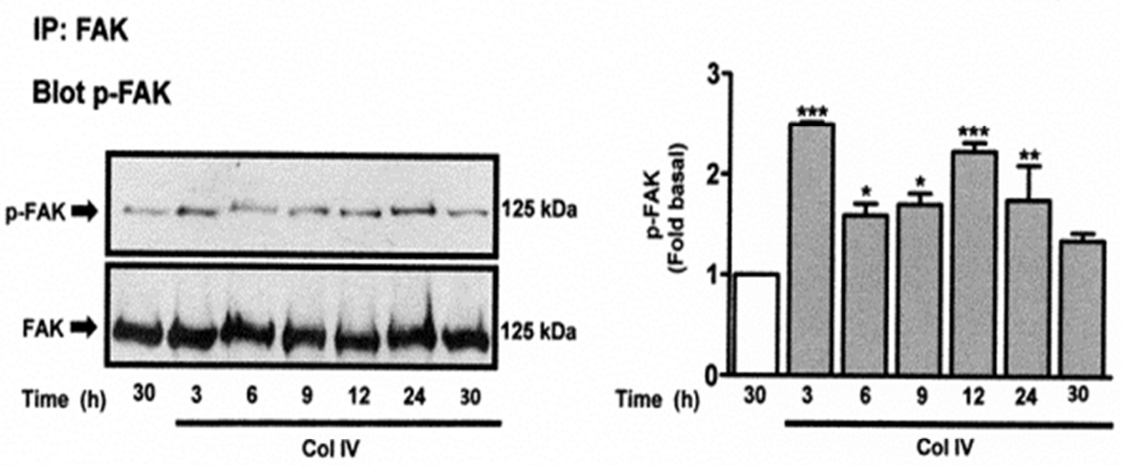

B
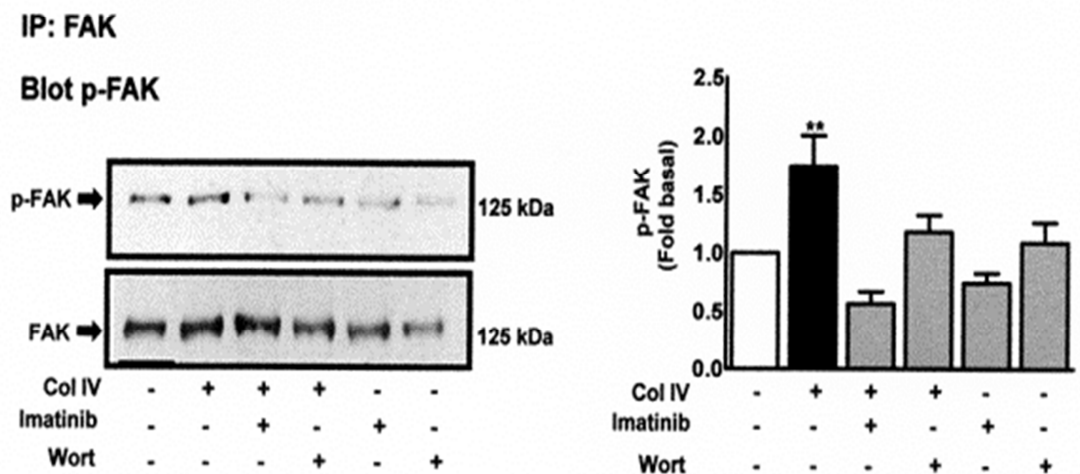

Figure 2. Native type IV collagen induces FAK activation through a DDRI and PI3K-dependent pathway. Panel A. MDA-MB-231 cells were treated without or with $7 \mu \mathrm{g} / \mathrm{ml} \mathrm{Col} \mathrm{IV} \mathrm{for} \mathrm{the} \mathrm{indicated} \mathrm{times} \mathrm{and} \mathrm{lysed.} \mathrm{Panel} \mathrm{B.} \mathrm{MDA-MB-231} \mathrm{cells} \mathrm{were} \mathrm{treated} \mathrm{without} \mathrm{(-)} \mathrm{or} \mathrm{with} \mathrm{(+)} 100 \mathrm{nM}$ imatinib or $100 \mathrm{nM}$ Wort, stimulated with $7 \mu \mathrm{g} / \mathrm{ml} \mathrm{Col} I V$ for $24 \mathrm{~h}$ and lysed. Lysates were analyzed by IP with anti-FAK Ab followed by Western blotting with anti-p-FAK Ab. The membranes were analyzed further by Western blotting with anti-FAK Ab. The graphs represent the mean \pm S.D. of at least three independent experiments and are expressed as fold of $p$-FAK above untreated cells. Asterisks denote comparisons made to untreated cells. ${ }^{*} P<0.05, * * P<0.01,{ }^{* * *} P<0.001$.

DDR1 and DDR2 present 15 and 14 tyrosine residues in their cytoplasmic domains respectively, which are phosphorylation sites upon receptor activation by collagens. The tyrosine phosphorylation sites recruit cytoplasmic signaling molecules containing $\mathrm{SH} 2$ domains and phosphotyrosine-binding (PTB) domains, which promote assembly of protein complexes able to transduce receptor signaling $[6,10]$. Particularly, native type I collagen promotes the association between the p85 subunit of PI3K with the tyrosine-881 of DDR1 in T47D cells [31]. In line with this notion, our findings demonstrate that native type IV collagen induces Akt 2 activation and that it is mediated by DDR1 and PI3K activity in MDA-MB-231 breast cancer cells.

Focal adhesions are the sites where integrins mediate adhesion links to the actin cytoskeleton and the ECM, their components are diverse and include scaffolding proteins, 
GTPases and kinases [32, 33].

A

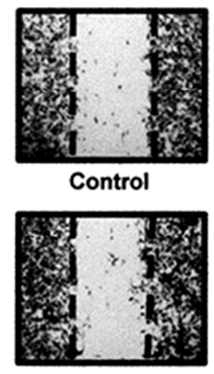

Col IV + Wort

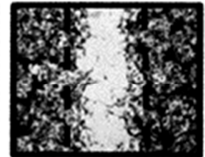

Col IV

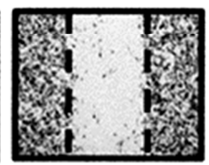

A6730

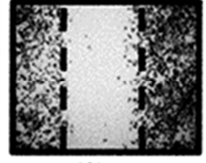

Wort

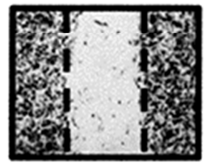

Col IV + A6730
B

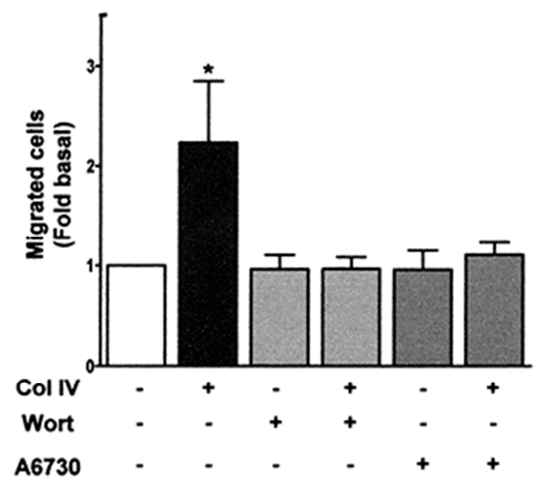

C

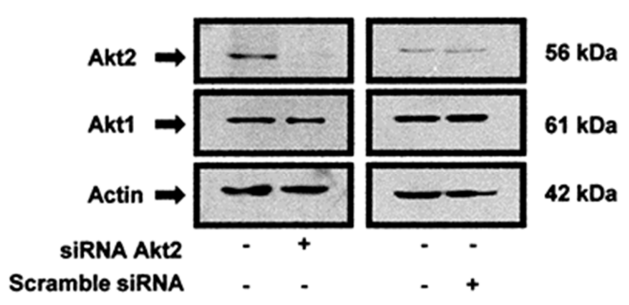

D
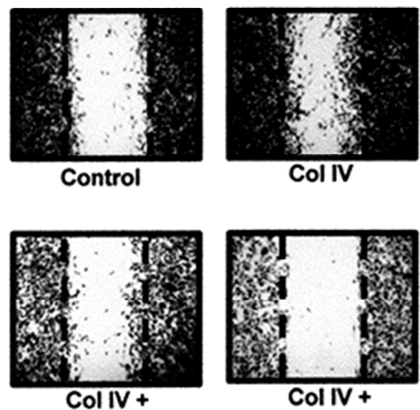

Scramble siRNA

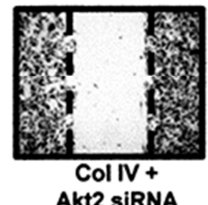

E

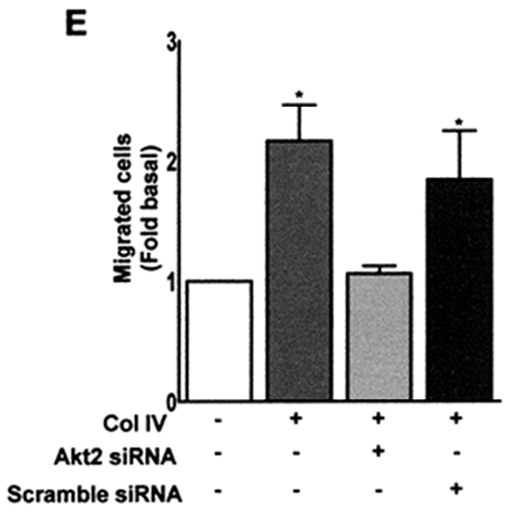

Figure 3. Role of PI3K/Akt2 on cell migration induced by native type IV collagen. Panel A. MDA-MB-231 cells were grown in 35 mm dishes and treated with 12 $\mu M$ mitomycin C for $2 \mathrm{~h}$. Cultures were scratch-wounded, treated with $100 \mathrm{nM}$ Wort or $2 \mu \mathrm{M}$ A6730 and stimulated with or without $7 \mu \mathrm{g} / \mathrm{ml}$ Col IV and pictures were taken at $48 \mathrm{~h}$ after wounding. Panel $B$. The graph is the mean $\pm S$.D. of at least three independent experiments and is expressed as fold of migration above untreated cells. Panel C. MDA-MB-231 cells were transfected with Akt 2 specific or scramble siRNAs. Akt2, Akt 1 and actin expression were analyzed by Western blotting with anti-Akt2 Ab, anti-Akt1 Ab and anti-actin Ab respectively. Ak1 and actin expressions were used as loading controls. Panel D. MDA-MB-231 cells were transfected with Akt2 specific or scramble siRNA. Cultures were scratch-wounded and stimulated with $7 \mu \mathrm{g} / \mathrm{ml}$ Col IV and pictures were taken at $48 \mathrm{~h}$ after wounding. Panel E. The graph is the mean \pm S.D. of at least three independent experiments and is expressed as fold of migration above untreated cells. $* P<0.05$.

FAK is a $125 \mathrm{kDa}$ protein tyrosine kinase localized to focal adhesions that can be activated by multiple agonists including ECM components and growth factors (EGF, $\mathrm{HGH}$ and PDGF).Activation of FAK is mediated by its autophosphorylation at Tyr-397, which is the docking site for $\mathrm{SH} 2$ domains of a number of signaling proteins including Src, PI3K and Grb7. FAK is implicated in the regulation of cell spreading, migration, differentiation, proliferation, apoptosis, invasion, survival and angiogenesis $[34,35]$. We previously demonstrate that native type IV collagen promotes migration through a DDR1-dependent pathway in MDA-MB-231 cells [25]. In line with this notion, we demonstrate here that native type IV collagen induces FAK activation through a DDR1 and PI3K-dependent pathway in MDA-MB-231 cells. These results are in agreement with a previous report demonstrating that cell migration mediated by FAK requires the activity of PI3K and the formation of FAK-PI3K complex [36]. 

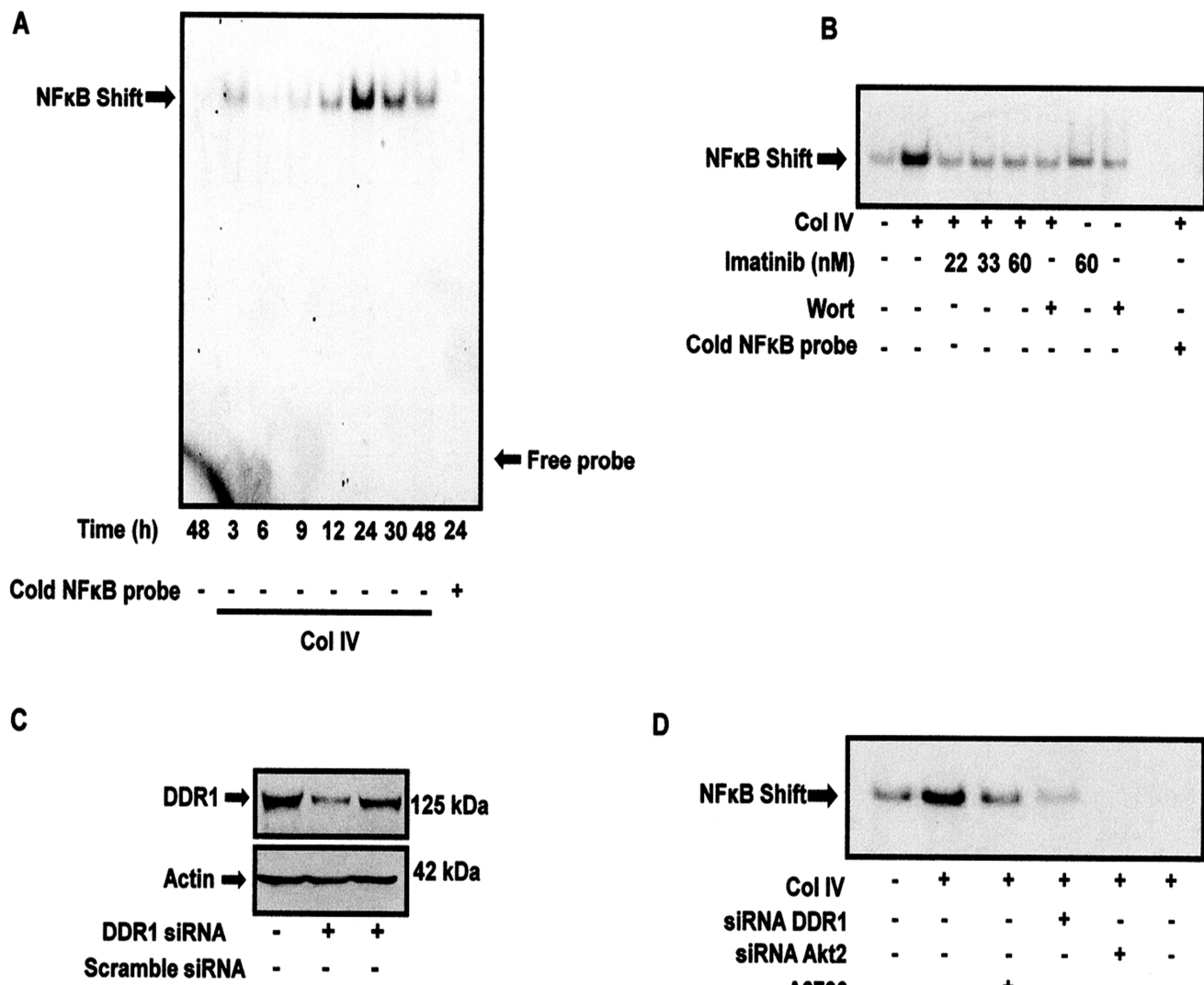

- Free probe

D

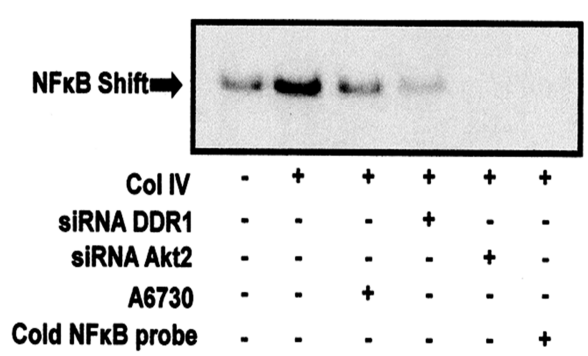

Figure 4. Role of DDR1 and PI3K/Akt2 on the increase of NFKB-DNA binding activity induced by native type IV collagen Panel A. MDA-MB-231 cells were stimulated without or with $7 \mu \mathrm{g} / \mathrm{ml} \mathrm{Col} \mathrm{IV} \mathrm{for} \mathrm{the} \mathrm{indicated} \mathrm{times} \mathrm{and} \mathrm{nuclear} \mathrm{extracts} \mathrm{were} \mathrm{obtained.} \mathrm{Panel} \mathrm{B.} \mathrm{MDA-MB-231} \mathrm{cells} \mathrm{were} \mathrm{treated} \mathrm{with} \mathrm{various}$ concentrations of imatinib (22, 33, $60 \mathrm{nM})$ and $100 \mathrm{nM}$ Wort, stimulated without or with $7 \mu \mathrm{g} / \mathrm{ml}$ Col IV and nuclear extracts were obtained. Panel C. $M D A-M B-231$ cells were transfected with DDR1 specific or scramble siRNAs. DDR1 and actin expression were analyzed by Western blotting with anti-DDR1 Ab and anti-actin Ab respectively. Actin expression was used as loading control. Panel D. MDA-MB-231 cells were treated with $2 \mu M A 6730$ and MDA-MB-231 cells transfected with DDR1 and Akt2 specific or scramble siRNAs were treated with $7 \mu \mathrm{g} / \mathrm{ml} \mathrm{Col} \mathrm{IV} \mathrm{and} \mathrm{nuclear} \mathrm{extracts} \mathrm{were} \mathrm{obtained.} \mathrm{NF} \mathrm{KB-DNA} \mathrm{binding}$ activity was analyzed by EMSA. Controls included EMSA reactions with 100-fold excess of cold NF KB probe as competitor. The autoradiographs shown are representative of at least three independent experiments.

The PI3K/Akt pathway regulates a variety of cell processes including, migration, proliferation, survival, protein synthesis, glucose metabolism and carcinogenesis [37, 38]. Particularly, Akt1 plays an important role in tumor development, whereas Akt2 participates in tumor invasion and metastasis in mouse models of oncogene-induced mammary tumorigenesis [39-41]. Here we demonstrate that native type IV collagen induces Akt2 activation, and that migration induced by native type IV collagen requires PI3K and Akt2 activity. We propose that native type IV collagen plays a pivotal role in migration/invasion process through the activation of PI3K and Akt2 in breast cancer cells. Supporting our proposal, we previously demonstrated that migration and invasion induced by arachidonic acid require PI3K and Akt activity in MDA-MB-231 breast cancer cells [42].

Akt phosphorylates a number of proteins, including IKB, which releases $\mathrm{NFKB}$ and allows it to translocate to the nucleus and activates target genes, such as those involved in inflammation, metastasis and apoptosis/survival. The transcription factor $\mathrm{NF \kappa B}$ is involved in cancer promotion, because it regulates the expression of many genes, including those involved in clonal expansion, growth, angiogenesis, adhesion, extravasation and degradation of ECM components $[43,44]$. Particularly, we previously demonstrated that arachidonic acid induces NFKB-DNA binding activity through a PI3K/Akt-dependent pathway in MDA-MB-231 breast cancer cells [42]. In line with this notion, here we demonstrate that native type IV collagen induces NFKB-DNA binding activity and that it is mediated by DDR1 and PI3K/Akt2 activity in MDA-MB-231 cells. We propose that degradation of BM and release of native type IV collagen induces the expression of genes implicated in the invasion/metastasis process through the activation of NFKB in MDA-MB-231 cells. Supporting our proposal, it has been demonstrated that $\mathrm{NF} \kappa \mathrm{B}$ mediates expression of tumor promoting genes, such as TNF, IL-1, iNOS and MMP-9 [43]. 
A

\section{IP: Akt2}
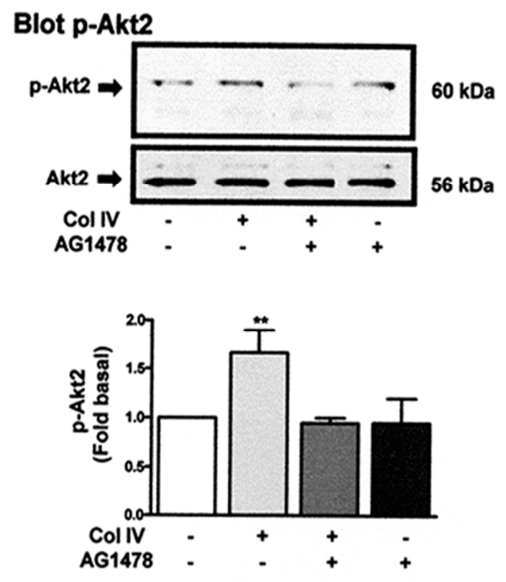

C

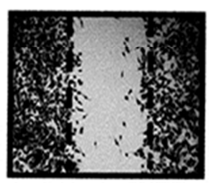

Control

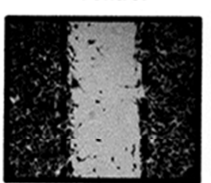

Col IV + AG1478

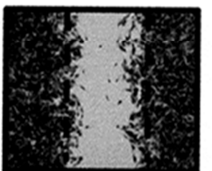

Col IV

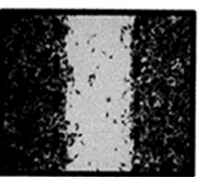

AG1478
B

IP: FAK

Blot p-FAK
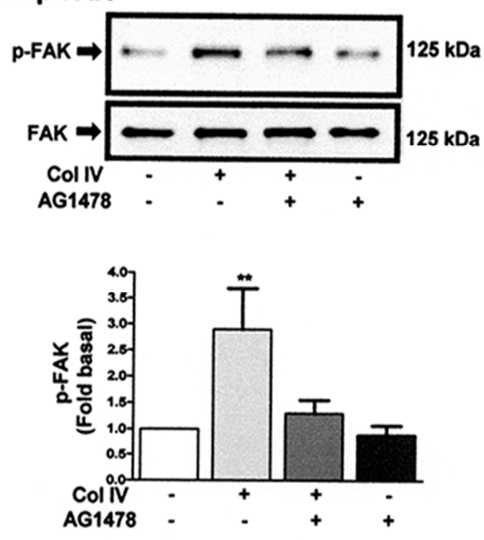

D

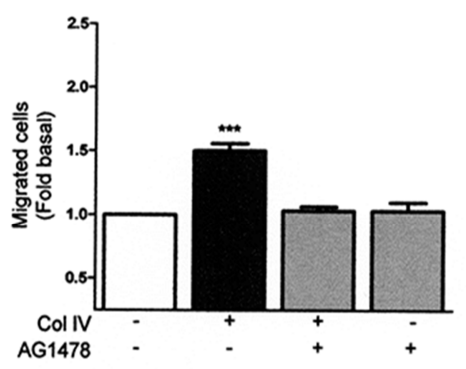

E

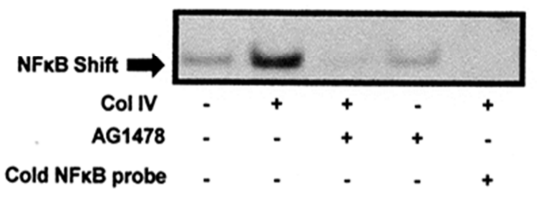

Figure 5. Role of EGFR on cell migration and $N F K B$ DNA binding activity induced by native type IV collagen. Panel $A$ and B. MDA-MB-231 cells were treated

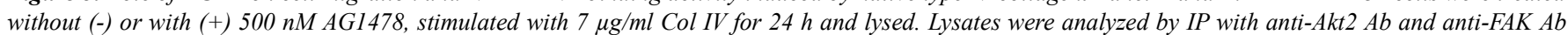
followed by Western blotting with anti-p-Akt2 Ab and anti-p-FAK Ab respectively. The membranes were analyzed further by Western blotting with anti-Akt2 and anti-FAK Ab respectively. The graphs represent the mean \pm S.D. of at least three independent experiments and are expressed as fold of p-Akt 2 or $p$-FAK above untreated cells. Panel C.MDA-MB-231 cells were grown in $35 \mathrm{~mm}$ dishes and treated with $12 \mu \mathrm{M}$ mitomycin C for $2 \mathrm{~h}$. Cultures were scratch-wounded, treated with $500 \mathrm{nM}$ AG1478 and stimulated with or without $7 \mu \mathrm{g} / \mathrm{ml} \mathrm{Col} \mathrm{IV} \mathrm{and} \mathrm{pictures} \mathrm{were} \mathrm{taken} \mathrm{at} 48 \mathrm{~h}$ after wounding. Panel D. The graph is the mean $\pm S . D$. of at least three independent experiments and is expressed as fold of migration above untreated cells. Panel E. MDA-MB-231 cells were treated with $500 \mathrm{nM} A G 1478$, stimulated without or with $7 \mu \mathrm{g} / \mathrm{ml} \mathrm{Col} \mathrm{IV} \mathrm{and} \mathrm{nuclear} \mathrm{extracts} \mathrm{were} \mathrm{obtained.} \mathrm{NF} \kappa B$-DNA binding activity was analyzed by EMSA. Controls included EMSA reactions with 100-fold excess of cold NFKB probe as competitor. The autoradiograph showed is representative of at least three independent experiments.

EGFR and Her-2 overexpression correlates with a reduction in survival and induction of invasion and metastasis in malignant breast cancer [45]. Furthermore, transactivation of EGFR induced by G-protein couple receptors (GPCRs) is a well-documented pathway that occurs via activation of metalloproteinases (MMPs) and subsequent release of epidermal growth factor (EGF)-like ligands, including HB-EGF, from growth factors precursors in the plasma membrane[46, 47]. Particularly, Src family kinases are suggested upstream and downstream mediators of EGFR activation in GPCRs-induced transactivation, where Src kinases play a role in the MMPs activation [46, 48]. In addition, EGFR transactivation is also mediated by ligands that activate RTKs including growth hormone and PDGF [49-51]. Our findings showed that Akt 2 and FAK activation, cell migration and NFKB-DNA binding activity induced by native type IV collagen require EGFR activity in MDA-MB-231 cells. Since, native type IV collagen promotes Akt2 and FAK activation through a DDR1/PI3K-dependent pathway and that migration and NFKB-DNA binding activity require DDR1, PI3K and Akt2 activity, we propose that activated DDR1 by native type IV collagen transactivates EGFR and then EGFR mediate PI3K activation, which mediate Akt2 and FAK activation, subsequently Akt2 mediates migration and NFKB-DNA binding activity in MDA-MB-231 cells. 
In conclusion, our findings demonstrate, for the first time, that native type IV collagen promotes FAK and Akt2 activation, which require DDR1, PI3K and EGFR activity in MDA-MB-231 breast cancer cells. Moreover, native type IV collagen induces cell migration and NFKB-DNA binding activity through a PI3K, Akt2 and EGFR-dependent pathway. Our findings define a new role of EGFR in the signal transduction pathway mediated by DDR1 activated with native type IV collagen in MDA-MB-231 breast cancer cells. Our results suggest that EGFR through PI3K and Akt2 activation play an important role in the migration/invasion process mediated by DDR1 in breast cancer cells.

\section{Acknowledgments}

We are grateful to Nora Ruiz for her technical assistance. This work was supported by a grant from ICYTDF (224/2012). E. R-U and O. G-H are supported by a CONACYT predoctoral training grant.

\section{References}

[1] Aumailley, M. \& Gayraud, B. Structure and biological activity of the extracellular matrix. J Mol Med (Berl) 76, 253-65, 1998

[2] Nagase, H. \& Woessner, J.F., Jr. Matrix metalloproteinases. J Biol Chem 274, 21491-4, 1999.

[3] Stetler-Stevenson, W.G., Liotta, L.A. \& Kleiner, D.E., Jr. Extracellular matrix 6: role of matrix metalloproteinases in tumor invasion and metastasis. FASEB J 7, 1434-41, 1993.

[4] Weaver, V.M. et al. beta4 integrin-dependent formation of polarized three-dimensional architecture confers resistance to apoptosis in normal and malignant mammary epithelium. Cancer Cell 2, 205-16, 2002.

[5] Oskarsson, T. Extracellular matrix components in breast cancer progression and metastasis. Breast 22 Suppl 2, S66-72,2013.

[6] Vogel, W.F., Abdulhussein, R. \& Ford, C.E. Sensing extracellular matrix: an update on discoidin domain receptor function. Cell Signal 18, 1108-16, 2006.

[7] Borza, C.M. \& Pozzi, A. Discoidin domain receptors in disease. Matrix Biol, 2013.

[8] Hou, G., Vogel, W. \& Bendeck, M.P. The discoidin domain receptor tyrosine kinase DDR1 in arterial wound repair. J Clin Invest 107, 727-35, 2001.

[9] Kamohara, H., Yamashiro, S., Galligan, C. \& Yoshimura, T. Discoidin domain receptor 1 isoform-a (DDR1alpha) promotes migration of leukocytes in three-dimensional collagen lattices. FASEB J 15, 2724-6, 2001.

[10] Valiathan, R.R., Marco, M., Leitinger, B., Kleer, C.G. \& Fridman, R. Discoidin domain receptor tyrosine kinases: new players in cancer progression. Cancer Metastasis Rev 31, 295-321, 2012.

[11] Dillon, R.L., White, D.E. \& Muller, W.J. The phosphatidyl inositol 3-kinase signaling network: implications for human breast cancer. Oncogene 26, 1338-45, 2007.
[12] Fresno Vara, J.A. et al. PI3K/Akt signalling pathway and cancer. Cancer Treat Rev 30, 193-204, 2004.

[13] Liu, P., Cheng, H., Roberts, T.M. \& Zhao, J.J. Targeting the phosphoinositide 3-kinase pathway in cancer. Nat Rev Drug Discov 8, 627-44, 2009.

[14] Vanhaesebroeck, B., Guillermet-Guibert, J., Graupera, M. \& Bilanges, B. The emerging mechanisms of isoform-specific PI3K signalling. Nat Rev Mol Cell Biol 11, 329-41, 2010.

[15] Engelman, J.A. Targeting PI3K signalling in cancer: opportunities, challenges and limitations. Nat Rev Cancer 9, 550-62, 2009.

[16] Matheny, R.W., Jr. \& Adamo, M.L. Current perspectives on Akt Akt-ivation and Akt-ions. Exp Biol Med (Maywood) 234, 1264-70, 2009.

[17] Robledo, T., Arriaga-Pizano, L., Lopez-Perez, M. \& Salazar, E.P. Type IV collagen induces STAT5 activation in MCF7 human breast cancer cells. Matrix Biol 24, 469-77, 2005.

[18] Santoro, S.A. \& Cunningham, L.W. Platelet-collagen adhesion. Methods Enzymol 82 Pt A, 509-13, 1982.

[19] Castro-Sanchez, L., Soto-Guzman, A., Guaderrama-Diaz, M., Cortes-Reynosa, P. \& Salazar, E.P. Role of DDR1 in the gelatinases secretion induced by native type IV collagen in MDA-MB-231 breast cancer cells. Clin Exp Metastasis 28, 463-77, 2011.

[20] Hodgson, L., Henderson, A.J. \& Dong, C. Melanoma cell migration to type IV collagen requires activation of NF-kappaB. Oncogene 22, 98-108, 2003.

[21] Buchdunger, E. et al. Abl protein-tyrosine kinase inhibitor STI571 inhibits in vitro signal transduction mediated by c-kit and platelet-derived growth factor receptors. J Pharmacol Exp Ther 295, 139-45, 2000.

[22] Bantscheff, M. et al. Quantitative chemical proteomics reveals mechanisms of action of clinical ABL kinase inhibitors. Nat Biotechnol 25, 1035-44, 2007.

[23] Day, E. et al. Inhibition of collagen-induced discoidin domain receptor 1 and 2 activation by imatinib, nilotinib and dasatinib. Eur J Pharmacol 599, 44-53, 2008.

[24] Li, J. et al. Wortmannin reduces metastasis and angiogenesis of human breast cancer cells via nuclear factor-kappaB-dependent matrix metalloproteinase- 9 and interleukin- 8 pathways. J Int Med Res 40, 867-76.

[25] Castro-Sanchez, L., Soto-Guzman, A., Navarro-Tito, N., Martinez-Orozco, R. \& Salazar, E.P. Native type IV collagen induces cell migration through a CD9 and DDR1-dependent pathway in MDA-MB-231 breast cancer cells. Eur J Cell Biol $89,843-52,2010$.

[26] $\mathrm{Hu}, \mathrm{C}$. et al. Opposite regulation by PI3K/Akt and MAPK/ERK pathways of tissue factor expression, cell-associated procoagulant activity and invasiveness in MDA-MB-231 cells. J Hematol Oncol 5, 16, 2012.

[27] Romashkova, J.A. \& Makarov, S.S. NF-kappaB is a target of AKT in anti-apoptotic PDGF signalling. Nature 401, 86-90, 1999 .

[28] Bishop, P.C. et al. Differential sensitivity of cancer cells to inhibitors of the epidermal growth factor receptor family. Oncogene 21, 119-27, 2002. 
[29] Liotta, L.A. \& Kohn, E.C. The microenvironment of the tumour-host interface. Nature 411, 375-9, 2001.

[30] Vogel, W., Gish, G.D., Alves, F. \& Pawson, T. The discoidin domain receptor tyrosine kinases are activated by collagen. Mol Cell 1, 13-23, 1997.

[31] L'Hote C, G., Thomas, P.H. \& Ganesan, T.S. Functional analysis of discoidin domain receptor 1: effect of adhesion on DDR1 phosphorylation. FASEB J 16, 234-6, 2002.

[32] DeMali, K.A., Wennerberg, K. \& Burridge, K. Integrin signaling to the actin cytoskeleton. Curr Opin Cell Biol 15, $572-82,2003$

[33] Wozniak, M.A., Modzelewska, K., Kwong, L. \& Keely, P.J. Focal adhesion regulation of cell behavior. Biochim Biophys Acta 1692, 103-19, 2004.

[34] Danen, E.H. \& Yamada, K.M. Fibronectin, integrins, and growth control. J Cell Physiol 189, 1-13, 2001.

[35] Chen, H.C. \& Guan, J.L. Association of focal adhesion kinase with its potential substrate phosphatidylinositol 3-kinase. Proc Natl Acad Sci U S A 91, 10148-52, 1994.

[36] Reiske, H.R. et al. Requirement of phosphatidylinositol 3-kinase in focal adhesion kinase-promoted cell migration. J Biol Chem 274, 12361-6, 1999.

[37] Manning, B.D. \& Cantley, L.C. AKT/PKB signaling: navigating downstream. Cell 129, 1261-74, 2007.

[38] Vivanco, I. \& Sawyers, C.L. The phosphatidylinositol 3-Kinase AKT pathway in human cancer. Nat Rev Cancer 2, 489-501, 2002.

[39] Dillon, R.L. et al. Akt1 and akt2 play distinct roles in the initiation and metastatic phases of mammary tumor progression. Cancer Res 69, 5057-64, 2009.

[40] Hutchinson, J., Jin, J., Cardiff, R.D., Woodgett, J.R. \& Muller, W.J. Activation of Akt (protein kinase B) in mammary epithelium provides a critical cell survival signal required for tumor progression. Mol Cell Biol 21, 2203-12, 2001.

[41] Hutchinson, J.N., Jin, J., Cardiff, R.D., Woodgett, J.R. \& Muller, W.J. Activation of Akt-1 (PKB-alpha) can accelerate ErbB-2-mediated mammary tumorigenesis but suppresses tumor invasion. Cancer Res 64, 3171-8, 2004.

[42] Villegas-Comonfort, S., Castillo-Sanchez, R., Serna-Marquez, N., Cortes-Reynosa, P. \& Salazar, E.P. Arachidonic acid promotes migration and invasion through a PI3K/Akt-dependent pathway in MDA-MB-231 breast cancer cells. Prostaglandins Leukot Essent Fatty Acids 90, 169-77, 2014.

[43] Prasad, S., Ravindran, J. \& Aggarwal, B.B. NF-kappaB and cancer: how intimate is this relationship. Mol Cell Biochem $336,25-37,2010$

[44] Ling, J. \& Kumar, R. Crosstalk between NFkB and glucocorticoid signaling: a potential target of breast cancer therapy. Cancer Lett 322, 119-26, 2012.

[45] Foley, J. et al. EGFR signaling in breast cancer: bad to the bone. Semin Cell Dev Biol 21, 951-60, 2010.

[46] Fischer, O.M., Hart, S., Gschwind, A. \& Ullrich, A. EGFR signal transactivation in cancer cells. Biochem Soc Trans 31, 1203-8, 2003.

[47] Prenzel, N. et al. EGF receptor transactivation by G-protein-coupled receptors requires metalloproteinase cleavage of proHB-EGF. Nature 402, 884-8, 1999.

[48] Pai, R. et al. Prostaglandin E2 transactivates EGF receptor: a novel mechanism for promoting colon cancer growth and gastrointestinal hypertrophy. Nat Med 8, 289-93, 2002.

[49] Yamauchi, T. et al. Growth hormone-induced tyrosine phosphorylation of EGF receptor as an essential element leading to MAP kinase activation and gene expression. Endocr J 45 Suppl, S27-31, 1998.

[50] Decker, S.J. \& Harris, P. Effects of platelet-derived growth factor on phosphorylation of the epidermal growth factor receptor in human skin fibroblasts. J Biol Chem 264, 9204-9, 1989.

[51] Saito, Y., Haendeler, J., Hojo, Y., Yamamoto, K. \& Berk, B.C. Receptor heterodimerization: essential mechanism for platelet-derived growth factor-induced epidermal growth factor receptor transactivation. Mol Cell Biol 21, 6387-94, 2001. 